\title{
Scottish missionary perceptions and images of amaXhosa in the nineteenth century
}

\section{Jongikhaya Mvenene}

\begin{abstract}
This article gives an analysis of the origins and early beginnings of mission stations among amaXhosa during the nineteenth century, which gradually became a centre of missionary activities among amaNgqika and amaGcaleka. This article analyses the history of the arrival and activities of the missionaries, east and west of the Nciba (Kei) River, in the nineteenth century. It also examines the role of the missionaries in shaping the relations among the traditional leaders and the colonial governors. The activities of the Scottish missionaries among amaXhosa are closely tied to the decline of traditional authority, power, control and influence, disintegration of amaXhosa chiefdoms and kingdom attended to by a loss of land and lives. The colonial government's forceful removal of amaNgqika from Ciskei in 1878 and resettlement in Gcalekaland is also brought to surface, as it is an example in point of how amaXhosa were rendered weak and fragile by the colonial governing authorities.
\end{abstract}

Keywords: Christianity, amaGcaleka, amaNgqika, conversion, resettlement, traditional authority

\section{Introduction}

To provide an account of the roots of the Scottish missionaries and their evangelical activities in Xhosaland, this article attempts to trace their roots back to the eighteenth and nineteenth centuries.

The amaXhosa traditional leaders (iiNkosi [chiefs] and iKumkani [kings]) have been badgered from pillar to post since their contact with the missionaries and colonialists in the seventeenth and eighteenth centuries. As a result, amaXhosa gradually became the victims of forced removals, unsettlement and resettlement. Against this background, it is prudent to examine factors that culminated in the socio-political, economic and cultural changes of amaXhosa. Since their arrival in amaXhosaland, the missionaries' presence caused strife, envy and divisions amongst amaXhosa. They played a major role in bringing about the subjection of African chiefdoms and kingdoms to magisterial rule and extension of white rule (Spicer, 1978; Mvenene, 1997; Wilson, 1969).

1. Dr Jongikhaya Mvenene is a lecturer in Curriculum Studies in History at the Mthatha Campus of Walter Sisulu University. He can be contacted at jmvenene@wsu.ac.za. 
The missionaries' trading relations with amaXhosa are a significant matter to be reckoned with as they contributed towards the decline of the economy of amaXhosa. The missionaries' arrival at the Cape in the 1820s marked a turning point in the history of amaXhosaland in terms of the sustenance and viability of their traditional religion and was a cause for confusion as they "brought Bibles in their right hands, and beads and buttons in their left" (Beck, 1989:211). Their setting foot in amaXhosaland also signalled the intensity of the sustained assault on the amaXhosa economy. UNkosi (Chief) Ngqika (Aa! Lwaganda!) - who was hailed uLwaganda kaMlawu ${ }^{2}$ - regarded the missionary's presence as a gesture of gaining prestige and access to a new source of power - Christianity (Elphick \& Davenport, 1997:69-70). The missionaries vehemently attacked African religion, regarding amaNgqika as having no religion, and further condemning their customs as barbaric (Hodgson, 1997:70).

Emphasising the growing interest of the missionaries in trading activities as compared to the preaching of the Word of God, Beck (1989:213) argues that other missionaries were so deeply involved in commercial relations with Africans that they "abandoned forever the holy book for the account book." The consequences of these activities are implied in Burns-Ncamashe's (1970:ix) assertion: "ukushumayela kwesizwe esiphanga umblaba namagunya kwabo sukuba sibashumayeza kumitha kade. Kuthi naxa ngelikade kuzalayo kuzale amanqaphanqapha" (Chalmers \& Soga, 1970:2) signifying that the preaching of the Gospel by those who were also intent on confiscating land and usurping chiefly power takes a considerably longer period to bear fruit. This was based on missionaries' discerning Christianity as aligned and closely intertwined with western civilisation and diametrically opposed to traditionalism. In the words of Elphick and Davenport (1997:4), "many early African Christians, like most missionaries, regarded Christianity and African religious views as mutually exclusive and even hostile to one another." However, there is no doubt that Christianity and western civilisation were - and are - two distinct processes.

\section{Working among amaXhosa}

The missionaries' two-pronged approach precipitated the widely held view and perception that being converted was tantamount to casting off one's own people (Cope,

2 UNkosi Mlawu (d. 1782), the heir of uNkosi Rharhabe (d. 1782), and brother of Ndlambe (d. 1828), was uNkosi Ngqika's (1778-1829) father. UNkosi Ngqika's ingoma was: iNjinana. His sons from various houses were Sandile (1820-1878), Maqoma (1798-1873), Tyhali (d. 1842), Anta (1810-1877), Xhoxho (d. 1878), Matwa (1810-1847) and Thente (d. 1842). To refer to uNkosi Ngqika as 'uLwaganda ka Mlawu' was a gesture of respect, affection and elevation. As a gesture of honour to, and expressing of respect for southern abeNguni traditional leaders, izikhahlelo (praise names) prefixed with $\mathrm{Aa}$ ! were, and are, used to acknowledge the presence of a traditional leader in a gathering of his/her people. 
1979:1, 4). To corroborate this point, reference to the view of a missionary who had been sent by the London Missionary Society (L.M.S), van der Kemp, who worked as a missionary among amaNgqika, is of significant relevance. Having engaged with amaNgqika in commercial activities, van der Kemp came to the conclusion that "the necessary articles of life may be obtained from ye Caffres by exchanging them for coarse cloth, linens, tobacco boxes, knives, scissors, needles, looking glasses, a few razors, night caps, old buttons and some blades of brass" (Beck, 1989:213). They exchanged these valueless commodities for cattle, sapping the economic base of amaNgqika in British Kaffraria (Ciskei since 1864) (Mvenene, 1997).

To put my argument in context, it is worth mentioning that van der Kemp laid the foundation for Reverends Joseph Williams and John Brownlee to set on the path of taking the evangelising crusade and campaign further. Accompanied by his wife and child, Williams of the L.M.S. arrived in British Kaffraria in 1816 and worked among amaNgqika under uNkosi Ngqika (1778-1829). The founder of the first permanent mission to the amaNgqika at the Ngxwengxwe (Kat) River, Joseph Williams, also served as the government agent, and like most missionaries, he "strove to inculcate in [amaXhosa] an appreciation for European trade goods and values, and a confidence in the beneficence of at least some forms of European rule" (Elphick, 1997:5). Nxele expressed his disaffection and disgust at Reverend Williams' presence among amaNgqika, and sounded a warning between 1816 and 1818: "There they come! They have crossed the Qhagqiwa (Zwartkops) River and they have crossed the Nqweba (Sundays) River; only one river more, the Nxuba (Fish) River, and they will be in our land. What will become of you then?" (Wauchope, 1908:34, quoted in Elphick \& Davenport, 1997:71). Nxele, the prophet of 1818-1819, had called on amaXhosa to leave evil ways so that the earth might be made 'right' (lunga) again (Peires, 1987:48). Nxele was a diviner and a war doctor of repute who led 9000 or 10000 soldiers in an attack on Grahamstown in the fifth frontier war of 1818. AmaXhosa were, however, defeated in the fifth frontier war (1818-1819). Nxele was thenceforth imprisoned on Robben Island, where he died in 1820 (Wilson, 1969:256, 265). He drowned as he attempted to escape. Hence, he never returned from Robben Island (Peires, 1987:59). However, Mlanjeni, the war-doctor and witchfinder, circulated the news that Nxele was still alive during the frontier War of 1850-1853. So much for Nxele and Mlanjeni.

The colonial government had masterminded the settling of Williams with the objective of befriending him with $u$ Nkosi Ngqika. Williams built a square house, a church with a schoolroom, a dam and irrigation furrow and practiced enclosure of land and new agricultural methods, but continued to uncompromisingly condemn the amaXhosa practices and customs, like "the use of red ochre for decorating the body, the paying of lobola (bridewealth), ancestor ritual, dancing, and the killing of 
suspected witches" (Hodgson, 1997:74). His equating of Christianity with western civilisation elicited $u N k o s i$ Ngqika's expression of discontent and revulsion. As he reacted to missionary cultural interference:

You have your manner to wash and decorate yourselves on the Lord's day and I have mine the same in which I was born and that I shall follow. I have given over for a little to listen to your word but now I have done for if I adopt your law I must entirely overturn all my own and that I shall not do. I shall begin now to dance and praise my beast as much as I please and shall let all who see who is Lord of this land (Holt 1954:80, quoted in Elphick \& Davenport, 1997:74).

On the death of Williams in 1818, Cape Governor Lord Charles Somerset set out to have another missionary stationed near $u$ Nkosi Ngqika's Great Place ${ }^{3}$ with the intention "of maintaining amicable relations with Gaika [Ngqika]" by having John Brownlee of the L.M.S. sent to Tyhume in 1820 not only as a missionary but also as a government agent (du Plessis, 1965:184). Subsequent to the death of the grandfather of William Kobe, Ntsikana, ${ }^{4}$ a Xhosa Christian prophet, in 1820, the Ngxwengxwe amaNgqika migrated to the Tyhume mission founded at Mgwali by Brownlee, a government missionary agent (Hodgson, 1997:75). Brownlee was joined by a government appointee, Ritchie Thompson of the Glasgow Missionary Society (G.M.S.) in 1821. The year 1823 saw William Thompson and John Bennie joining Brownlee at Tyhume to begin and accelerate the evangelising work of the G.M.S. (Hodgson, 1997:75). Thus Peires, in Elphick and Giliomee (1989:486), aptly remarks that "the period 1820-1835 also saw a vast upswing in missionary activity", alluding to Williams' arrival in amaXhosaland as a precursor to intensive missionary activities.

As a result of their sterling work at Tyhume, Williams and Brownlee produced amagqobhoka (converts), such as Robert Balfour (uNoyi), John Love, Elizabeth Love, Mary Ann and Charles Henry (uMatshaya), being named after prominent Scottish people, and the amaNtinde chief Dyani Tshatshu. Thus, their work gave rise to the emergence and rise of a 'civilised' class called amagqobhoka. Noyi was the son of Gciniswa, a disciple of Ntsikana, and one of the first five amagqobhoka baptised by Brownlee in 1823 (Opland, 1997:306). The Scots mission gave birth to Lovedale, Burnshill and Pierie stations, while through the work of John Ross there was a printing press. Schools, linguistic work, translations and publishing char-

3 The Great Place refers to chief's or king's place of residence, iKomkhulu.

4 Ntsikana (d.1822) was popularly known for his ingoma: ulo Tixo mkulu/ uloNgub'enkulu, which was recorded in 1844 by Ludwig Dohne, a Germany missionary working among amaXhosa. See Jacob Ludwig Dohne, Das Kafferland und sein Bewohner (1844:69-70).

5 Amagqobhoka is isiXhosa word referring to those converted to Christianity. 
acterised the Tyhume Mission (Shepherd, 1940:58, cited in Elphick \& Davenport, 1997:75). Houses in the mission were structured in a colonial-style: in a square fashion with two rooms allowing for marital privacy; rondavels were built at the back of the main house; local hardwood was used for the construction of doors and furniture; there were enclosed gardens and burial ground was laid out (Hodgson, 1997:76). Thus the Tyhume mission resembled a Scottish village.

It is worth noting that $u N k o s i$ Ngqika's acceptance of the missionaries was not so much for their Christian teachings as for their expediency in such secular matters as diplomacy and technology (religious and moral teaching). Also important was that the missionaries strategically founded mission stations near $i N k o s i$ 's (chief's) iKomkbulu (Hodgson, 1997:76). Having a missionary and a mission station near the iKomkhulu had little to do with religion, and was considered by traditional leaders as a symbol of earning much respect and inflating prestige and as an asset in dealing with the colonial government (Cope, 1979:1, 4; Hodgson, 1997:76). In the same fashion, uKumkani (King) Sarhili (1809-1892) urged the stationing of missionaries in amaGcalekaland in 1865 but made it clear that their presence was for political reasons (Chalmers, 1877:374-378).

For example, uKumkani Hintsa (1789-1835) expressed his dissatisfaction with the colonial traders' and missionaries' tendency of not always consulting iiNkosi and iiKumkani before penetrating the country, asking "who gave that man the right to go about my country showing the people his goods?" (Grahamstown Journal, 11 May 1833, cited in Elphick \& Giliomee, 1989:487). UKumkani Sarhili (Aa! Ntaba!) ignored the religious and educational activities of the missionares, and scoffed at whites' dress code as a gesture of his dislike of western civilisation (Ayliff, British Agent with Sarhili, to Brownlee, February 2, 185: 45; Blue Book, G. 16 - '76, Reports by Reverends R.S. Leslie \& J. Dewar, 1876:45-46). One of the amaXhosa iNkosi (chief) expressed his displeasure and complained tha "'when my people become Christians they cease to be my people", indicating that conversion was an invasion of their sovereignty (Calderwood, 1858:210-211, cited in Elphick \& Davenport, 1997:79).

IiNkosi complained in response to the penetration of their society by traders and missionaries having noted that colonial traders did not engage in trading interactions with their people in good faith. They realised that they had lost control of their own economy (Peires, 1989:487). It was most unwelcome to amaXhosa that the missionaries who also served as government agents provided the colonial government with the information relating to sensitive matters affecting their chiefdoms and kingdom, risking their security and rendering them vulnerable to colonial attacks. Government agents also relayed unpalatable messages from the government to traditional leaders. Brownlee is an example in point as he was in- 
structed by Somerset in 1822 to apprise $u N k o s i$ Ngqika that his intention to return to the neutral territory ${ }^{6}$ was to be counteracted, to condemn what was viewed as his unbecoming conduct and to accuse him of having brewed a conspiracy to invade the colony (Holt, 196: 39). Williams had tried to defend and rationalised their role as government agents and the attitude of the government towards amaXhosa. He upheld and justified their practice of being dishonest in dealing with amaXhosa traditional leaders and betraying amaXhosa. He argued that the "Government has given me permission to come here [amaXhosaland] to betray them and give them over to the English" (Holt, 1976:54).

The arrival of John Bennie, a catechist, and Reverend John Ross at the Tyhume Mission in November 1821 laid the foundation for the establishment and the development of the Church of Scotland in South Africa, both east and west of the Nciba River. From the Tyhume Mission, the Church of Scotland gradually spread far and wide across amaXhosaland, reaching amaGcalekaland in $1878^{7}$. Bennie and Ross started a mission to the southeast of the Tyhume River in 1824, which came to be known as the Ncerha Mission. The institution of Ncerha Mission brought in its train momentous changes in the lives of amaNgqika as they began to view life in a novel fashion due to their embracing of extraneous, reactionary Christian religion which had no room for the recognition of African systems of education, civilisation, concept of labour, time, religion, beliefs, culture, customs and practices - condemning these phenomena as heathenish, devilish and anti-Christian. The missionary activities at the Tyhume and Ncerha missions ushered in a new era in the history of what was termed the Rhabe Church. $^{8}$

Evidently, Bennie and Ross were no different from other missionaries in South Africa who had embarked on a notorious practice of launching "open, illogical and unwarranted attacks on the [ama]Xhosa customs and rites" (Williams, 1959:312). As people began to embrace Christianity thereby becoming amagqobhoka, Scottish missionaries continued to drive a wedge into the House of Phalo. ${ }^{9}$ To that effect, they further enforced that amagqobboka should dissociate themselves from

6 The neutral territory lay between the Nxuba River and the Xesi (Keiskamma) Rivers.

7 However, Thuthurha Mission at Chief Maphasa's area of jurisdiction was founded by Reverend Tiyo Soga in 1868. In 1878, Columba Mission was founded by Reverend James Macdonald Auld along the Khobonqaba River.

8 The word Rhabe is a corrupted form of Rharhabe. Since the Presbyterian Church missionaries arrived in amaRharhabeland in response to uNkosi Ngqika's request to the colonial government, the Presbyterian Church was known as the Church of amaRharhabe. As people of mixed ancestry (formerly known as coloureds) could not pronounce Rharhabe, they shortened it as the Rhabe Kerk.

9 The amaXhosa nation comprises amaGcaleka and amaNgqika. AmaGcaleka belonged to the Great House of uKumkani Phalo (d. 1775). AmaNgqika descended from uKumkani Phalo's Right-Hand House. AmaNgqika are also called amaRharhabe. 
$a^{a m a q a b a^{10}}$ (non-converts). It is worth noting that the danger of Christianity lay in the fact that there were two class divisions within amaXhosa, viz. amagqobboka and amaqaba.

Amagqobhoka were settled on the mission stations and were weaned from the jurisdiction of the traditional leaders, paying allegiance to the missionaries and therefore collaborating with the colonial authorities (Oliver, 1952:63). As a result of the missionaries' practice of urging amagqobhoka to ignore traditional leaders, it was not far-fetched to maintain that "the missionary became, in one sense, the rival of the chief" (Chalmers, 1877:268). The sinister objective of the missionaries of enforcing division on the basis of acceptance of Christianity was to set in motion a train of fissions which dismantled the amaXhosa's socio-political, religious and cultural threads which had held them intact (Maphasa, Interview, Centane, June 19, 2014; Phikisa, Interview, Centane, June 20, 2014; Tyhali, Interview, Centane, June 14, 2013). However, amaXhosa had some conflicting relations based on power relations. At the centre of these conflicts was the European and missionary interference in their relations.

\section{The missionaries and the wars of dispossession}

With the passage of time, amagqobhoka were also urged to pay allegiance not to their iiNkosi and iiKumkani but to the missionaries, as this was corroborated by the former siding with whites during some of the nine wars of dispossession, namely, the first frontier war (1779-1781), the second frontier war (1789-1793), the third frontier war (1779-1803), the fourth frontier war (1812), the fifth frontier war (1818-1819), the sixth frontier war (1835), the seventh frontier war (1846-1847), the eighth frontier war (1850-1853) and the last frontier war (1877-1878).

AmaXhosa lost tremendously during and after these wars of conquest and dispossession. During the first frontier war, amaXhosa lost to the whites approximately 65 327 herds of cattle, 11000 sheep and 200 horses. 23000 cattle were confiscated from $u N k o s i$ Ndlambe in 1818. In 1835, 60000 cattle were captured from amaXhosa by the colonial forces. It was a heavy blow for amaXhosa that at the cessation of the seventh frontier war all their land stretching from the Nxuba River to the Nciba River was annexed to the British crown. Even worse, during the wars of 1834-1835, 1850$1853,1877-1878$, colonial forces engaged in burning the amaXhosa homesteads and iiNkosi's and iiKumkani's amaKomkbulu (Great Places).

It was a traumatic experience and horror for the traditional leaders during the War of Mlanjeni (1850-1853), when much to their disgust, "some 1500 converts

${ }_{10}$ Amaqaba is isiXhosa word meaning those not converted to Christianity. 
to Christianity, belonging to the various missions, had consistently refused to join the insurgents and had retired for safety to Qonce (King William's town), where they remained until the close of hostilities" (Du Plessis, 1965:188). This action by the amagqobhoka bore testimony to the success of the policy of divide-and-rule, which dismantled social and cultural cohesion among amaXhosa. At the close of the war, the missionaries were increasingly antagonistic towards traditional leaders, and in turn, amaXhosa became more hostile to the Christian religion (Du Plessi, 1965: 295).

Seizure of land, cattle, killing of people and the destruction of property of amaXhosa by whites was more destructive than curative. The shifting of boundaries by the colony was another assault on amaXhosa, bringing the latter to the brink of poverty. For example, in 1806, the boundary between amaXhosa and whites was the Nxuba River; in 1811 uNkosi Ndlambe and 20000 of his subjects were evicted across the Nxuba River; in 1819 the area between the Nxuba River and the Xesi River was declared the neutral territory and was occupied by whites in 1824 . In 1847, the boundary was shifted to the Nciba River. Consequently, by the end of the War of Ngcayechibi, amaXhosa were landless, despondent and disarmed, having fought desperately though not militarily strong enough to match the colonial armies. However, before the influence of the Gospel and its undesirable divisional effects, amaXhosa were not always divided in their response, reaction and resistance to colonial assault and land dispossession. When Christianity set in, there was a division between amaqaba and amagqobhoka, which extended to their convergence on matters relating to their relations with the whites.

The work of Bennie and Ross was temporarily undone when Ncerha Mission was ruined during the sixth frontier war in which uKumkani Hintsa, a symbol of the amaXhosa nationalism, was shot dead by a white commoner and a scout, George Southey, a descendant of the 1820 British settlers, at the Nqabarha stream, in Gatyana (Willowvale) on 12 May 1835. Hintsa (Aa! Zanzolo!) was shot on the pretext by Colonel Harry Smith and Southey that he was trying to escape. Peire (1981: 111) portrays a gloomy, barbaric and sad picture of how $u$ Kumkani Hintsa faced his death at the hands of a white commoner:

He was pulled off his horse, shot through the back and through the leg. Desperately he scrambled down the river bank and collapsed into the watercourse... Southey, coming up fast behind him, blew off the top of his head. Then some soldiers cut off his ears as keepsakes to show around the military camps. Others tried to dig out his teeth with bayonets.

Despite all the damages Ncerha Mission suffered, however, it was later rebuilt as Lovedale Mission on the west banks of the Tyhume River, which "remained its situ- 
ation to this day" (Du Plessis, 1965:186). Named after the first Secretary of G.M.S., Dr John Love, Lovedale Mission played a major educational and Christianising role as it set out "to Christianise the natives [and] to train teachers for native schools" (Ayliff to Secretary for Native Affairs [SNA], February 11, 1874:42). As mentioned elsewhere in this article, from Lovedale Mission sprang up Balfour, Pirie and Burnshill missions. At the end of the sixth frontier war, Lovedale Mission was burnt down and wiped out of existence; Pirie missionaries were dispatched to Burnshill "to be under the powerful protection of Suthu, the great widow of [uNkosi] Gaika [Ngqika and Prince Sandile's mother], who had always shown marked kindness to white people" (Du Plessis, 1965:185). From these small beginnings at the Ncerha River, spread far and wide right across amaXhosaland, the word of God from amaNgqikaland to amaGcalekaland from 1856 to 1905 (Mvenene, 2016:25).

\section{The great python which encircled Hohita}

UKumkani Sarhili's (1809-1892) life was punctuated with setbacks and challenges. Throughout his life and times, he was badgered from pillar to post by the colonial governing authorities. Before the Nongqawuse cattle-killing mania (1856-1857), amaGcalekaland stretched from the Mbhashe River to Bhayi (Port Elizabeth) and extended as far north as Komani (Queenstown). It also encompassed iSidutyini (St Mark's) and Hohita in Cofimvaba (Mcothama, Interview, Centane, September 24, 1999; Ndenze, Interview, Centane, September 22, 1999). However, at the time, the towns of East London, Qonce and Komani were not yet in existence until after the War of Ngcayechibi (Peires, 1990:21). Wielding much power, uKumkani Sarhili was considered as great, valiant, defensive, dignified and fearful. As his praise poem reads, "Yinamb' enkulu ejikel' iHohita. Ovuk' emini akabonanga nto. Kub' engayibonang' inamb' icombuluka", signifying: He is the great python which encircles Hohita. He who is a later riser would have missed something. If he fails to witness the uncoiling of the python (Gqoba, 1906:228). This poem reflects that $u$ Kumkani Sarhili, uNkomo zimalunga nezikayise ${ }^{11}$, had a great dynasty before whites usurped the power, authority and influence of the traditional leaders. At the time, uKumkani Sarhili lived at his iKomkhulu, Hohita, in Cofimvaba.

UKumkani Sarhili was the eldest son and the heir of uKumkani Hintsa by his great wife, uKumkanikazi (Queen) Nomsa, who was the daughter of $u$ Nkosi Gambushe (the grandfather of Moni) of amaTshezi of the amaBomvana. Throughout his lifetime, Sarhili had held a grudge against whites on account of his father's violent and disgraceful death. He had been subjected by whites to various forms of ridicule, humiliation and disdain.

${ }_{11}$ This signified that he had as many cattle as his father's. Hintsa owned as many cattle as twice the number of amaGcaleka, who by 1809 numbered about 100000 and owned 360000 cattle (see Wilson, 1969:107). According to Peires (1990:21), Sarhili's cattle "had been numbered in tens of thousands" before the cattle-killing mania. 
Not only did he lose cattle, grazing land and lives to whites but he also experienced pressures from white traders and farmers. He also felt the brunt of missionary encroachments in his land. Peires (1990:18) argues that farmers, missionaries, governors and war generals had one common denominator, that is, the ideology of racism. Equally so, was their common aim of perpetuating the subjection of African chiefdoms and kingdoms for different reasons and in order to achieve different results. Thus, the missionaries, though proclaiming Christianity as the ideal religion suited to the Blacks as well, gradually became more pro-imperialist than being evangelistic, as the progress of the amaXhosa conversion was initially slow (Pauw, 1975:68).

For the greater part of the first half of the nineteenth century, missionaries had vainly exhausted all peaceful means of converting amaXhosa to Christianity. However, amaXhosa regarded conversion as a matter of disloyalty to traditionalism, especially when the missionaries expressed a belief that the amaXhosa's "salvation depended, not on their ancestry, but on a personal conversion to Jesus Christ" (Elphick, 1997:23). This view was precipitated by the missionaries' practice of challenging "the established system of authority in the tribe in a variety of ways" (Price, 2008:97). Having made little progress towards the conversion of the native people, the missionaries realised that slow conversion progress necessitated the dismantling of the power and influence of the traditional leaders so as to render them impotent by eroding their power among their subjects. Elphick and Davenport (1997:2-3) aver that missionaries usually made a few amagqobhoka, though they founded schools, translated the Bible into isiXhosa and studied African languages. Noticeably, was the pattern of a slow Christianising pace among amaXhosa. As Elphick and Davenport (1997:4) state: "Among some people, like the [ama]Xhosa and [ama]Zulu, still on the fringes of encroaching colonialism, the response to Christianity was cooler, with most rulers wary of missionaries, at least at first; the few converts in these societies came overwhelmingly from among outcast and marginal social groups."

Consequently, the second half of the nineteenth century saw missionaries advocating British rule with the express purpose of implanting western civilisation in amaXhosaland with the hope that once chiefly power was shattered and dismantled and the amaXhosa society disintegrated, the influence of the Gospel would be more generally diffused (Davenport, 1991:162). Their work rendered the colonial and mission work inseparable as they had since complemented each other (Majeke, 1952:65).

\section{Unsettlement and re-settlement: The exodus to Southern AmaGcalekaland}

AmaGcaleka under uKumkani Sarhili who inhabited Centane before and during the War of Ngcayechibi experienced a difficult, painful, violent, disastrous and tarnished relationship with the British. The British agent with Sarhili, James Ayliff, 
described them as "behind any tribe in the country and noted that there appears to be simply a disinclination to embrace Christianity" though they treated missionaries with respect (Ayliff to SNA, February 11, 1874:41).

The War of Ngcayechibi had far-reaching implications for amaGcaleka and amaNgqika. Resenting white intrusion into his territory, Sarhili took up arms as a last desperate attempt to offset British expansion, thwart the imposition of colonial rule, defend and sustain the amaXhosa autonomy and independence which had been wrested by the colonial government through the wars of dispossession. OoNkosi (chiefs) Sitokhwe Ndlela of the amaVundle and Mfanta of the abaThembu rendered valuable military assistance to uKumkani Sarhili. Before amaNgqika joined the war, ooNkosi Sandile and Kona were at Khubusi in Cumakala (Stutterheim). UNkosi Kona had amicable relations with amaMfengu who were about to cross the Nciba River. When amaMfengu lost 103 sheep en route across the Nciba River, uNkosi Kona helped them to retrieve their sheep using the spoor system (Auld, 1924:125). He, however, advised them not to cross the Nciba River because of the ensuing war.

UNkosi Kona also advised Reverend James Macdonald Auld who was stationed at Lujilo Mission in Cumakala, to remove his family to Mgwali for fear of imminent trouble that was brewing, saying: "I cannot say that there will be trouble, but let the missionary keep his family at Emgwali meantime" (Auld, 1924:125). Khiva, with a number of amaGcaleka, had crossed the Nciba River from Gcalekaland "with the evident purpose of stirring up the Gaikas [amaNgqika] to rebellion" (Auld, 1924:125). As uNkosi Sandile and his people - all armed with assegais - were gathering to take a decision on whether to join the war or not, a magistrate, Wright, and a policeman, Ngangelanga, joined the gathering with a view to convince Sandile not to participate in the war. Mr. Wright advised Sandile to consult his chief amaphakathi $^{12}$ (councillors), namely, Tyhala, Soga and Gaqa, as well as ooNkosi Feni and Kona of amaNgqika. Nevertheless, amaNgqika joined the war on the 31st December 1877. Sandile and his amaphakathi, save Soga and a large part of amaNgqika, entered the war. However, Soga went with Sandile into the Amathole bush on account of his attachment to the latter. AmaMfengu found shelter at Mgwali Mission where they were welcomed by Dukwana, a headman on the Mgwali Mission, and Auld. All their stock had been taken from them. One of them was wounded. A rich Mfengu, Adonis, approached the resident missionary, Cumming, and asked him if he would take charge of a sum of 500 pounds which was in his

12 Amaphakathi were drawn usually from the traditional leader's age-mates and chosen from the richer homestead heads; as senior members of the commoner clans, they were not only the mediators between the chief and his subjects but were also the main decision makers in the Great Place - KomkhuIu. Their authority was derived from the people. For more on this aspect, see Switzer (1993:36). 
possession (Auld, 1924:126). Cumming promised to take and bank it on the following day. Unfortunately, Adonis was killed and his people fled to Sandile's brother, Ngonyama (Aa! Dondashe!), who gave them sanctuary. Adonis' son went back to his father's homestead and found the money hid in the cattle kraal.

The first week of January 1878 saw a meeting held at the Mgwali Mission to discuss war-related matters. But Dukwana did not attend until the third occasion whereupon the residents asked Cumming to read Sir Bartle Frere's (1815-1884) Proclamation which promised 'protection' to the mission on condition that its residents remained 'loyal'. However, 20 families left the mission as they were not prone to being 'loyal'.

Despite outside military assistance, Sarhili was decisively beaten at the Battle of Centane in February 1878. According to Saunders, the war "enabled the colony to seize [not only] Gcalekaland [but also] Bomvanaland" (Saunders in Saunders \& Derricourt, 1974:186). No sooner was uKumkani Sarhili extensively devastated than amaGcalekaland was brought under Cape magisterial rule. The war was not only one of the bloodiest frontier wars but it also considerably influenced the pace of whites' extension of control to ubuKhosi and ubuKumkani of the amaXhosa nation.

After the defeat of amaXhosa, the colonial government set out to ease pressure in the Ciskei. Using amaGcalekaland as a dumping ground for the unwanted, though 'loyal', amaNgqika and amaMfengu ${ }^{13}$ and also intent on making more land available for white farmers, Cape Prime Minister John Gordon Sprigg (1830-1913) who became Prime Minister from 1878 to 1881, declared in July 1878 his government's objective to expel the 'loyal' amaNgqika from west of the Nciba River to Centane, Southern Gcalekaland. Consequently, the 'loyal' amaNgqika of ooNkosi Feni, Kona and the recently deceased Anta and the followers of Tyhala were forced to leave amaNgqikaland and settle in amaGcalekaland (Cape Argus, 6 August 1878). However, Tyhala, the people of Anta and the amaNgqika at Greytown ${ }^{14}$ expressed their

${ }^{13}$ AmaMfengu were scattered refugees from the amaHlubi, amaBhele and amaZizi chiefdoms of Natal, who set foot in Gcalekaland from 1822 onwards (see Wilson, 1969:259; and Cope, 1979:15); Sir George E. Cory's interview with Maseti, Centane, Jan. 1910, Cory Accessions, MS 68 - 125. Born at Alice, Maseti was about 14 years during the death of uKumkani Hintsa on 12 May 1835. However, during the 1980s the amaMfengu and their origins have become a source of lively debate. Having been precipitated by Cobbing, the amaMfengu debate has been expanded by Webster and Stapleton. Webster denounces the notion that the amaMfengu were the remnants of Shaka's victims from Natal. He disputes any holding of these refugees as bondsmen by uKumkani Hintsa. He regards the story of the amaMfengu as devoid of truth and full of exaggeration. He asserts that whites invented the story to justify their extraction of labour and cattle from Hintsa's people whom whites had enslaved. He points out that whites disguised their enslavement of amaXhosa as philanthropic activity, see Cobbing (1984 and 1988); Wright (1989); Webster (1991); Stapleton (1995:357-360).

${ }^{14}$ Greytown is now part of the town of Stutterheim; it was established for the German military settlers of 
aghast at the government's plan, but to no avail (Cape Argus, 3 September 1878). They were promised of seed mealies and food supply until reaping time. The government also told them that the land in Centane was being surveyed and that each man would be given ten acres of arable land (Auld, 1924:138). Hence September 1878 saw amaNgqika crossing the Nciba River and settled in the land between the Ngunduza Hill and the Nciba River. The land stretching from the Nciba to Qolorha road and between the Qhorha and Manyube was earmarked for whites' farms. However, this did not take off as it was viewed as objectionable and unsuitable. In the process, white farmers acquired land confiscated from the expelled iiNkosi of amaNgqika. In September 1878 the Greytown people were resettled in two locations of 20000 acres in Centane, followed by Anta's to two other locations, totalling 7664 people, including 1019 men and 6665 cattle (Wright to SNA, September $28,1878)$.

Some amaGcaleka had been resettled along the Qhorha River; others across the Mbhashe River. AmaGcaleka of $u N k o s i$ Maphasa's (1835-1894), however, remained at Thuthurha. Oral tradition has it that between Maphasa's amaGcaleka and amaNgqika, three amaMfengu locations, namely, Nkondwane, Qhina and Sigangala were created by the Cape Prime Minister (Dlulisa, Interview, Centane, September 30, 1999; Mtirara, Telephone Interview, December 28, 2014; Sandile, Interview, Centane, October 2, 1999), while uNkosikazi (Chieftainess) Noposi, Sandile's widow, and many amaNgqika were placed at Qombolo (Auld, 1924:138). Captain Blyth became the Chief Magistrate of the Transkei. He was stationed at Ntlambe.

Pesika Mfaxa (Interview, Centane, June 17, 1999) revealed that Sandile's great son, Gonya, had been given as heir to Noposi who had given birth to a daughter, Vitoliya. Having been released from prison, Gonya was given a farm at Chwarhu in eXesi (Middledrift). But Gonya left for Qombolo in Centane with Noposi, sending his son, Faku, and wife, Nokapa, to his farm at Chwarhu. However, his son, Velile, was forcefully removed from Chwarhu and stationed at Pirie where he had his iKomkhulu, uMngqesha (Mfaxa, Interview, Centane, June 17. 1999).

Paradoxically, the amaNgqika did not escape colonial assault and repression even though they had to pay huge prices during and after the war. For instance, the amaNgqika incurred loss of lives. The heir, though not the eldest son, of uNkosi Ngqika, uNkosi Sandile (Aa! Mgolombane!) was ruthlessly killed at Izidenge forest where he was interred on June 9, 1878 (Auld, 1924:137). His brothers, Matana and Xhoxho (the latter being not the son of Chief Maphasa of amaGcaleka), were butchered and killed at the Bholo drift of the Nciba River and at Qolorha, respectively. Falayi, the eldest son of Xhoxho, was also killed at Qolorha. Khiva, Siyolo and 
other leading men were also killed. Those who survived the brutality of murderous colonial government were taken prisoners of war. UNkosi Sandile's brothers, Somta and Ngwana, were taken beyond the Kei Road station and were subsequently dumped at Pirie forest. The sons of $u$ Nkosi Maqoma (Aa! Jongumsobomvu!), Thini, Yaphi and Mapolisa were taken to Fort Beaufort, Alice and Gqumahashe, respectively (MS 14 254/13).

AmaNdlambe and imiDushane (tributaries of $u b u K h o s i$ of amaNgqika were also subjected to the severe and ruthless treatment of the colonial government. The eldest son and heir of $u N k o s i$ Mdushane, ${ }^{15}$ Prince Siyolo, was killed at Mvane beyond the Xesi River. Nomjezu, son of Siyolo, and Manana, son of Mazwi, were killed at Debe Nek. Maclean, son of Qasana (brother of Siwani), Mesani, son of Ngwana (cousin to Siyolo), Jali, son of Mqhayi (cousin to Makinana) and Sidokolo, son of Manana, were slain at the Ntaba-kaNdoda mountain. The surviving sons of Mhala (brother of Makinana), namely, Ndimba, Mayezile and Nathaniel were charged with sedition and taken prisoners of war. Mhala's brother, Nowewi, and three sons of Siyolo did not evade imprisonment. It is, however, worth noting that the above list does not purport it to be exhaustive, as "the above were chiefs of note. Many other petty chiefs were killed and others captured" (MS 14 254/13). Those who delivered themselves up and those who were taken prisoners were deported to Western Province where they were imprisoned or served for a term of years (Auld, 1924:138).

The surviving chiefs and their sons were tried. On 23 October 1878, Sandile's sons, namely, Gonya (Edmund), Matanzima and Gumna, and his nephew, Jan Mayaba, were tried and were found guilty of sedition by Justice Sir JD Barry. Edmund was sentenced to life imprisonment with hard labour; Matanzima who was also accused of having killed Adonis at Bholo was sentenced to twenty years imprisonment; Gumna was sentenced to fifteen years hard labour, and Jan Mayaba's sentence was ten years hard labour.

\section{Conclusion}

The perceptions and attitudes of the missionaries towards amaXhosa were not entirely positive. The missionaries' interest to evangelise Africans was coupled with their desire to engage in trading relations with amaXhosa. To advance Christianity, missionaries saw the amaXhosa's reverence for their culture as a stumbling block to conversion, their declared purpose. Ardent to succeed in their declared mission, the missionaries embarked on a new path - open and illogical attack on the amaXhosa customs, culture and tradition. The complexity of the socio-political and

${ }_{15}$ UNkosi Mdushane (d. 1829) was the brother of uNkosi Mhala (d. 1875) and son of uNkosi Ndlambe (d. 1828). 
cultural landscape was exacerbated by such administrators as J.C. Warner who "scarcely differentiated between the spread of the Gospel and the spread of the British Empire or, at least, of white rule" (Warren, 1965:42). In this new role, the missionaries' activities complemented that of the colonial governing authorities, as is evidenced in the participation of amagqobhoka during some of the wars of dispossession, siding with whites. This divided allegiance of amagqobboka, and the missionaries' continued assault on traditionalism led to the gradual weakness and subjection of ubuKhosi and ubuKumkani of amaXhosa. It brought about the demise of the House of Phalo.

\section{References}

Beck, R.B. 1989. Bibles and beads: Missionaries as traders in Southern Africa in the early nineteenth century. Journal of African History 30, 209-215.

Blue Book on Native Affairs. 1875. G. 21 - '75. James Ayliff, British Agent with Sarhili, to Brownlee. 2 February 1875.

Blue Book. 1878. G. 27 - '74. James Ayliff, British Agent with Sarhili, to Secretary for Native Affairs. 11 February 1874.

Blue Book. 1878. G.17 - '78. Wright to SNA. 28 September 1878.

Burns-Ncamashe, S.M. 1970. Isihlahla ndlela somhleli. In J.A. Chalmers \& T.B. Soga (eds). UTiyo Soga. Lovedale: Lovedale Press.

Calderwood, H. 1997. Caffres and the caffre missions. In R. Elphick and R. Davenport (eds). Christianity in South Africa: A political, social and cultural history. Cape Town: David Philip.

Cape Argus, August 6, 1878.

Cape Argus, September 3, 1878.

Chalmers, J.A. 1877. Tiyo Soga. Edinburgh.

Cobbing, J. 1984. The case against the Mfecane. Unpublished paper presented to a seminar at the University of the Witwatersrand.

Cobbing, J. 1988. The Mfecane as alibi: Thoughts on Dithakong and Mbolompo. Journal of African History 29(2), 488-500.

Cope, R.L. 1979. Christian missions and independent African chiefdoms in South Africa in the early 19th century. Theoria 2, 1-15.

Cory Accessions, MS 68 - 125, Sir George E. Cory, Interview with Maseti, Centane, January 1910.

Cory Library, PR 1272, James M. Auld, 'Reminiscences', in Blythswood Review, October 1924; Auld, 'Reminiscences', in Blythswood Review, December 1924.

Davenport, T.R.H. 1991. South Africa: A modern history. London: Macmillan.

Dlulisa, Vizinto (Chief), Interview, Sigangala Location, Centane, September 30, 1999.

Dohne, J.L. 1844. Das kafferland und sein bewohner. Berlin.

Du Plessis, J. 1965. A history of Christian missions in South Africa. Cape Town: C. Struik. 
Elphick, R. 1997. Christianity in South African history. In R. Elphick \& R. Davenport (eds). Christianity in South Africa: A political, social and cultural history. Cape Town: David Philip.

Gqoba, W.G. 1906. Isizathu sokuxhelwa kweenkomo ngoNongqawuse. In W.B. Rubusana. Zemk' iinkomo magwalandini. Lovedale: Lovedale Press.

Grahamstown Journal, May 11, 1997. In R. Elphick \& H. Giliomee (eds). The shaping of South African society, 1652-1840. Cape Town: Maskew Miller Longman, 1989.

Hodgson, J. 1997. A battle for sacred power: Christian beginnings among the Xhosa. In R. Elphick \& R. Davenport (eds). Christianity in South Africa: A political, social and cultural history. Cape Town: David Philip.

Holt, B. 1954. Joseph Williams and the pioneer mission to the southeastern Bantu. Lovedale: Lovedale Press.

Holt, B. 1976. Greatheart of the border: A life ofJohn Brownlee, pioneer missionary in South Africa. King William's Town: South African Missionary Museum.

Holt, B. 1954. Joseph Williams and the pioneer mission to the south - eastern Bantu. Lovedale: Lovedale Press.

Maphasa, Dumehleli (Chief), Interview, Thuthurha Location, Centane, June 19, 2014.

Majeke, N. 1952. The role of the missionaries in conquest. Cumberwood: APDUSA.

Mcothama, Gawushigqili (Chief), Interview, AmaKhweleshe komKhulu, Centane, September 24, 1999.

Mfaxa, Pesika, Interview, Macibe Location, Centane, June 17, 1999.

MS $14254 / 13$.

Mtirara, Mvuyo, Telephone Interview, December 28, 2014.

Mvenene, J. 2016. Reverend James Macdonald Auld and the disintegration of traditional leadership in Xhosaland. African Historical Review 48(2), 24-42.

Mvenene, J. 1997.The origins of the division of Thembuland, 1828-1913. Master's dissertation, University of Transkei.

Ndenze, Robert, Interview, Lusizi Location, Centane, September 22, 1999.

Oliver, R. 1952. The missionary factor in east Africa. London: Macmillan.

Opland, J. 1997. The drumbeat of the cross: Christianity and literature. In R. Elphick \& R. Davenport (eds). Christianity in South Africa: A political, social and cultural history. Cape Town: David Philip.

Pauw, B.A. 1975. Christianity and the Xhosa tradition: Belief and ritual among Xhosaspeaking Christians. Cape Town: Oxford University Press.

Peires, J.B. 1990. The annexation of Transkei. Journal of Human Sciences 1(1), 20-38.

Peires, J.B. 1997. The British and the Cape, 1814-1834. In R. Elphick \& H. Giliomee (eds). The shaping of South African society, 1652-1840. Cape Town: Maskew Miller Longman.

Peires, J.B. 1987. The central beliefs of the Xhosa cattle-killing. Journal of African History 28(1), 48-59.

Peires, J.B. 1981. The house of Phalo: A history of the Xhosa people in the days of their independence. Johannesburg: Ravan Press.

Peires, Jeff Brian (Emeritus Professor of History, University of Fort Hare), Telephone Interviews, December 26, 2019. 
Phikisa, Vululwandle (Chief), Interview, Nyumaga Location, Centane, June 20, 2014.

Price, R. 2008. Making empire: Colonial encounters and the creation of imperial rule in nineteenth century Africa. New York: Cambridge University Press.

Sandile, Dumalisile (Chief), Interview, Macibe Tribal Authority, Centane, October 2, 1999.

Saunders, C. 1974. The annexation of the Transkei. In C. Saunders \& R. Derricourt (eds). Beyond the Cape frontier: Studies in the history of the Transkei and Ciskei. London: Government Printer.

Shepherd, R. 1997. Lovedale, South Africa: The story of a century, 1841-1941. In R. Elphick \& R. Davenport (eds). Christianity in South Africa: A political, social and cultural history. Cape Town: David Philip.

Spicer, M.W. 1978. The war of Ngcayechibi, 1877-18 8. Master's dissertation, Rhodes University.

Stapleton, T.J. 1995. Oral evidence in a pseudo-ethnicity: The Fingo debate. History in Afric, 22, 350-360.

Switzer, L. 1993. Power and resistance in an African society: The Ciskei Xhosa and the making of South Africa. Pietermaritzburg: University of Natal Press.

Tyhali, Mthetheli (Chief), Interview, Godidi Location, Centane, June 14, 2013.

Warren, M. 1965. The missionary movement from Britain in modern history. London: Macmillan.

Wauchope, I. 1997. The natives and their missionaries. In R. Elphick \& R. Davenport (eds). Christianity in South Africa: A political, social and cultural history. Cape Town: David Philip.

Webster, A.C. 1991. Land expropriation and labour extraction under Cape colonial rule: The War of 1835 and the 'emancipation' of the Fingo. Master's dissertation, Rhodes University.

Williams, D. 1959. The missionaries on the eastern frontier of the Cape colony, 1791853. $\mathrm{PhD}$ thesis, University of the Witwatersrand.

Wilson, M. 1969. Co-operation and conflict: The Eastern Cape frontier. In M. Wilson \& L. Thompson (eds). The Oxford history of South Africa, vol. 1. Oxford: Oxford University Press.

Wilson, M. 1969. The Nguni people. In M. Wilson \& L. Thompson (eds). The Oxford history of South Africa, Vol. 1. Oxford: Oxford University Press.

Wright, J. 1989. Political mythology and the making of Natal's Mfecane. Canadian Journal of African Studie, 23(2), 37-58. 
